\title{
Do Macroeconomic Variables Affect Stock Market Performance? A Case Study of DSEX and DS30 Index of Dhaka Stock Exchange
}

\author{
Md. Emran Hasan (Corresponding author) \\ Lecturer, Department of Economics, Bangladesh University of Professionals \\ Mirpur Cantonment, Dhaka-1216, Bangladesh \\ Tel: 880-151-5244-794Ｅ-mail: emran.hasan@ @up.edu.bd
}

Md. Shahanawaz Sharif

Lecturer, Department of Economics, Bangladesh University of Professionals

Mirpur Cantonment, Dhaka-1216, Bangladesh

Tel: 880-176-9021-930Ｅ-mail: shahanawaz.sharif@bup.edu.bd

Received: July 18, 2019 Accepted: August 2, 2019 Published: August 20, 2019

doi:10.5296/ber.v9i3.15109 URL: https://doi.org/10.5296/ber.v9i3.15109

\begin{abstract}
Stock market performance- being the linchpin of an economy, requires variations in policies concerning macroeconomic variables. Keeping this in notion, this research assays the empirical association between stock market performance and a few selected macroeconomic variables namely interest rate, exchange rate, inflation rate, and 91-days Treasury bill rate using monthly data ranging from January 2013 to October 2018. Employing Johansen Cointegration analysis, the results of the study suggest that exchange rate and treasury bill rate are positive whereas interest rate and inflation rate are negatively associated with better stock market performance. Granger causality test implies bidirectional causality - between the interest rate and DS30 as well as DSEX while unidirectional causality is evident for both the indices which are running from interest rate, inflation and exchange rate to stock market performance. Formulation and implementation of prudent policies regarding the studied macroeconomic variables can lead to a healthy stock market outcome.
\end{abstract}

Keywords: Stock Market Performance, Macroeconomic Variables, Dhaka Stock Exchange JEL classifications: E44; G10; G12 


\section{Introduction}

The stock market is inextricably linked with the overall economy of a country. One of the main indicators is the stock market to demonstrate the financial sector's performance of an economy, just like the barometer is for weather condition. The stock market, being the significant part of any economy's structure, can help flourish the macroeconomic situation and boost up the economic growth through bridging private investors and investing firms (Muktadir-Al-Mukit, 2013). Various macroeconomic factors, on the contrary, influence stock market performance i.e. interest rate, exchange rate, inflation rate, treasury bill (T-bill) etc. (Modigliani \& Cohn, 1979; Chen et al., 1986; Joseph et al., 2006; Kuwormu, 2012; Mgammal, 2012; Mbulawa, 2015). This phenomenon offers the opportunity to examine the empirical relation between the macroeconomic variables and the performance of the various stock indices as a whole (Rahman \& Uddin, 2009).

Empirical evidence suggest that interest rate - a major determining factor of investment as well as economic growth, appears to affect the performance of stock market negatively (Uddin, 2009; Muktadir-Al-Mukit, 2012 \& 2013; Eita, 2014). Khan et al. (2012) on the contrary, showed that the stock market performance is negatively but insignificantly affected subject to change in interest rate while Mbulawa (2015) and Al-Naif (2017) provided mix evidence on the question of the nexus between these two variables. Exchange rate - another important indicator of macroeconomic performance of any economy have mixed evidence in constructing the performance of the stock market of the economy as suggested by many researchers. In addition, both inventory prices and the exchange rate are determined over time (Dornbusch \& Fischer, 1980). Some researchers showed that exchange rate significantly and positively influences the stock prices as well as stock market (Aggarwar, 1981; Giovannini \& Jorion, 1987; Roll, 1992; Ahmed et al., 2010; Muktadir-Al-Mukit, 2013; Bala \& Hassan, 2018) while some others provided evidence of the existence of a negative relationship (Soenen \& Hennigar; 1988). Besides these counter-intuitive results, some studies have suggested that the exchange rate has an insignificant relation to the efficiency of the stock market (Nieh \& Lee, 2001; Muhammad et al., 2002; Bhattacharya \& Mukherjee; 2003).

Since there has been a debate over how inflation rate is influencing the performance of stock market and thereby make a balance between the financial market as well as the goods market and finally macroeconomic stability of any economy. Previous empirical researches provide mixed evidence on this question. Choudhry (2001), Maysami et al. (2004) and Mohammed et al. (2007) found that inflation rate exerted positive stimulus on the stock market yield. Kuwornu (2012), by contrast, showed that stock returns are significantly and positively related with rate of inflation while Khan et al. (2012) illustrated that inflation rate appears to have an insignificant effect on stock returns and Mgammal (2012) substantiated the mixed evidence in this regard. Policies concerning with macroeconomic factors especially treasury bill (T-bill) rates are critically important since treasury bill rates play a noteworthy role in the stock market stabilization in response to any disruption caused by either any internal or external shocks. Prior studies provided substantial mixed evidence on the interaction between treasury bill rates and stock market returns. Taking time length into consideration, treasury bill rates affect stock market returns oppositely - negatively in the short run whereas 
positively in the long run (Kuwornu, 2012). However, Mbulawa (2015) evidenced that T-bill rates have negative effects on stock market performance. Aforementioned extensive discussions reveal that macroeconomic variables have a significant mixed effect on stock market performance. This mixed evidence justifies the rationale to conduct further research in this arena.

A series of studies have been conducted to analyze and find out the actual relationship between interest rate, exchange rate, and stock market indices, especially the general index (DSE General Index - DGEN) in Bangladesh (Muktadir-Al-Mukit, 2012 \& 2013). Not much of the researchers are not conducted to reveal the scenario for the newly introduced two indices - DS30 and DSEX in 2013. This paper, in this backdrop, attempts to investigate the effects of macroeconomic variables on the performance of the mentioned two new stock indices using monthly data from January 2013 to December 2018. This study, with a view to analyzing the nexus among the macroeconomic factors and stock market performance, employs different econometric techniques especially the time series techniques.

The current research is organized into several sections. After the Introduction in Section 1, Section 2 sheds light on Bangladesh's stock market followed by a review of existing empirical literature in Section 3; Afterwards, Section 4 highlights the methodology of this study while section 5 provides a detailed explanation of the empirical findings obtained from the econometric tests performed; Finally, Section 6 concludes with some of the recommendations.

\section{The Stock Market in Bangladesh: An Overview}

Bangladesh, in the post-independence period, reverted to the path of development although slow in pace, from the position of 'bottomless basket' as stated by some of the developed countries. While experiencing positive growth in the manufacturing as well as some other sectors, initialization of policy reformation in the 1990s to modernize the country's financial sector added an impetus in this regard (Muktadir-Al-Mukit, 2013). According to Bangladesh Bank, financial sector in Bangladesh, based on differing extent of regulation, is consisted of three subsectors broadly e.g. formal (basically regulated by the Central Bank), semi-formal (regulated by different regulatory system i.e. independent regulatory framework - other than the Central Bank) and informal (completely out of any kind of regulation). There are currently 64 commercial banks (59 scheduled banks and 5 non-scheduled banks), 34 non-banking financial institutions (NBFIs), 62 insurance companies (life insurance firms 18 and non-life insurance companies 44), 599 micro finance institutions (MFIs) and lastly two stock markets e.g. Dhaka Stock Exchange (DSE) and Chittagong Stock Exchange (CSE). There are other statutory authorities with their own legislative frameworks, such as the Insurance Development \& Regulatory Authority (Insurance Authority), the Securities \& Exchange Commission (Capital Market Intermediaries Regulatory Authority) and the Microcredit Regulatory Authority (MFI Authority) under the umbrella of the Central Bank Bangladesh Bank as the Bangladesh economic sector's apex regulatory body. (https://www.bb.org.bd/fnansys/index.php).

In early 1954, Bangladesh's first stock market had its platform with the establishment of East 
Pakistan Stock Exchange Association Ltd. and later on, it was renamed as Dacca Stock Exchange Ltd. (DSE) in 1964. Despite founded in 1954, its operations started formally in 1956. During the liberation war in 1971, all activities of DSE was halted and in the post-independence era, DSE's transactions were commenced again in 1976 aligning with the country's new economic policies. Currently, there are 581 listed companies under DSE and the market capitalization is around BDT 4,149.07 billion (https://www.dsebd.org/market-statistics.php). On the other hand, Chittagong Stock Exchange (CSE) - the country's second stock exchange started its journey in 1995. At present, approximately 425 companies are listed under CSE and the market capitalization is about BDT 3,442.04 billion (https://www.cse.com.bd/market/historical_market). Since 1971, Bangladesh experienced two major stock market crashes - the first one was in 1996 and the second one was in 2011 popular as a stock market bubble (Rahman et al., 2017). Consequently, market capitalization amplified nearly 1.1 times while turnover declined about 61.7 percent - the largest fall in the history for DSE General Index (DGEN). Moreover, around 3.3 million people were affected directly as well as indirectly due to the collapse in the stock market occurred in 2011 (Saha, 2012). After the dramatic downturn in the stock market of Bangladesh, the central bank - Bangladesh Bank and Bangladesh Securities and Exchange Commission (BSEC) undertook timely policies to stabilize the market. According to Saha (2012), the stock market started following increasing trend gradually with some institutional buyers like merchant banks, state-owned banks, and non-financial institutions bought more shares rather than selling. However, Bangladesh's stock market is characterized by ups and downs and the performance is yet far behind the expected level despite favorable policies are taken by relevant stakeholders (Rahman et al., 2017).

\section{A summary of existing Literature}

According to current literature, macroeconomic variables appear to have an unclear impact on stock market performance. Reviewing of literature is conducted in two stages: firstly, literature from the perspective of other countries other than Bangladesh to find out how macroeconomic factors are linked with stock market performance, secondly, Bangladesh related literature has been reviewed to have an extensive idea and to identify the literature gap.

\subsection{Context of Countries other than Bangladesh}

Muhammad et al. (2002) attempted to investigate whether stock prices and exchange rates are interrelated or not using proof from South Asian countries namely Bangladesh, India, Pakistan and Sri Lanka using monthly information from January 1994 to December 2000 as part of the strategy to Cointegration, VECM and Granger Causality. The result showed no short-run connection for each of the four countries between the said factors. There is also no long-term link for Pakistan and India between stock prices and exchange rates. Nevertheless, these economic factors offer the feeling that they are a bi-directional causality.

Li and Huang (2008) published an evaluation on China the place the relationship between stock return and the exchange rate had been the core subject. The goal was once to explore the relationship between the RMB exchange rate and A-share stock returns specially in the 
Shanghai inventory market of China. Here, Engle-granger cointegration, pairwise Granger causality showed no cointegration, which means no lengthy run affiliation amongst variables. Moreover, change rate Granger causes stock market return.

Hsing (2011) aimed to observe the results of macroeconomic variables on the inventory market index in the setting of one of the BRICS nations - South Africa using exponential GARCH model and quarterly information over the duration 1980Q2 to 2010Q3.The study summed that amongst selected macroeconomic indicators domestic real interest rate, nominal effective exchange rate, and inflation rate affect stock market index negatively.

With an aim to discover the results of three macroeconomic variables particularly activity rate, alternate rate and inflation on inventory market returns for Kingdom of Saudi Arabia (KSA), Khan et al. (2012) used monthly records from 31 July 2001 to 30 June 2010. They applied more than one regression model and determined that all the explanatory variables have a trivial impact on inventory market returns (returns of KSE 100 index) without the rate of inflation.

Mgammal (2012) studied the outcomes of some macroeconomic variables (e.g. inflation, pastime rates, and trade rates) on stock fees for two GCC international locations - KSA and UAE. Analyzing each monthly and quarterly data, the researcher established that exchange rate positively influence inventory expenses in the quick run for UAE only while in the long run, the exchange price is substantially associated with stock fees for UAE. However, for KSA, stock costs are significantly affected by inflation.

Kuwornu (2012) analyzed the Ghanaian Stock Market Returns effect with the aid of inspecting macroeconomic indicators through co-integration econometric technique. Monthly records from January 1992-December 2008 had been accrued to study Johansen multivariate cointegration and ECM. Key findings of the paper are - inflation is the most momentous in both the short run and long run; in the short run, Treasury bill and inflation - significantly stimuluses stock returns whereas inflation rate, crude oil prices negatively, exchange rate and Treasury bill rate are positively significant where Treasury bill is also inelastic in the long run.

Khan et al. (2012) investigated the have an effect on of activity rate, trade price and inflation on inventory returns of KSE a hundred index. Multiple regression model had been used by means of examining month-to-month facts from 31st July 2001 to thirtieth June 2010. There was a vulnerable relationship between the dependent variable and independent variables. Existence of trivial linkage amongst the considered variables was evident in their findings. Despite the return of KSE 100 index is significantly influenced by the exchange rate, the case is the opposite for interest rate and exchange rate.

Paramati and Gupta (2013) showed an empirical relationship between change rate, activity rates, and stock returns to empirically take a look at the nexus between call money rates, trade quotes and stock returns from the standpoint of India the use of VAR and Granger causality. The end result confirmed that unidirectional causality from each call cash quotes and exchange price to stock returns. Moreover, Var suggests - Lead-lag from call money to both 
exchange rate and stock returns and exchange rate to call money rates and stock returns but the reverse is not true.

For Jordan, Bekhet and Matar (2013) investigated each the quick and lengthy run empirical relationship between various macroeconomic indications and stock rate index the use of annual facts from 1978-2010. Employing ARDL certain check approach, they concluded that- industrial production, money supply, exchange rate, and discount rate show up to have long-run relationship with stock rate index.

Eita (2014) regarded interest rate and inventory market returns in Namibia and tried to set up the causal relationship between them. Cointegrating VAR model and Granger causality showed a neagtive relationship between inventory market returns and interest rate and bi-directional causality between stock market returns and interest rate in Namibia respectively.

Taking four Asian international locations specifically Indonesia, Korea, Philippines, and Thailand into account, Lim and Sek (2014) tried to explore the inter-association between the volatility of change rate and stock return considering two one-of-a-kind periods - pre-IT (inflation targeting) and post-IT periods. Employing GARCH and VAR econometric techniques and annual records from January 1990 to December 2012, they concluded that existence of bi-directional causal relationship (significant) between change price volatility and return of shares for the international locations - Indonesia, Korea, and Thailand. On the contrary, for these three countries, some macroeconomic variables i.e. interest rate, money supply, international reserves, lag of exchange rate volatility can cause both exchange rate and return of stocks significantly.

In the milieu of Zimbabwe, Mbulawa (2015) applied Vector Error Correction Model (VECM), Johansen Cointegration and Granger causality test with an intention to look at the connection stock market overall performance and some of the macroeconomic variables - exchange rate, Treasury bill rate, and interest rate. Employing month-to-month information from January 1980 and December 2008, the findings demonstrated the various effect of interest rate on inventory market performance amidst the pre-inflationary stage and unidirectional causality jogging from inventory market performance to all the regarded macroeconomic variables. However, all through the hyperinflationary period, regardless of the treasury bill's negative have an impact on on the stock market performance, trade rate and deposit fee affect the stock market overall performance oppositely. two Moreover, causality analysis published that bidirectional causality is evident between the stock market and exchange rate whereas unidirectional causality is found from stock market performance to the interest rate.

The study conducted by way of Msindo (2016) used VAR and Granger causality strategies and month-to-month statistics ranging from June 1995 to September 2014 for the South African stock market. The researcher found an insignificant relationship between exchange rate and stock returns. Finally, the authors concluded by referring interest rate as an fallacious predictive tool.

Mouna and Anis (2016) examined the market and determined that all through the monetary 
crisis, hobby price and alternate price threat results on the financial stock. The paper used AGARCH-M method and investigated the monetary sector's stock return sensitivity situation to market, interest rate, and risk in monetary services, banking, and insurance plan sectors in eight countries, such as the economies of China, the U.S., and a variety of European countries. GARCH in the mean model and volatility spillover analyzed statistics from 2006-2009. There had been widespread wonderful as well as terrible consequences of the stock market returns, interest rate, and exchange price volatility of the financial sector for the duration of the crisis. They also showed that positive and negative volatility spillovers significantly from the market return, interest rate, exchange rate and interest rate in the financial services and the banking sector. Moreover, this finding is evident in both European and the United States economies amid the crisis.

Babajide et al. (2016) studied inventory market response to economic growth and interest rate volatility in Nigeria via inspecting the relationship between macroeconomic variable volatility and stock market return inside the context of Blanchard (1981) extension of the Hicks (1937) IS-LM hypothesis. EGARCH had been used the usage of month-to-month records from January 1985-December 2013. The response of stock fees to any shock in the interest charge and the real gross home product (RGDP) is non-trivial.

Considering the context of Zambia, Musawa and Mwaanga (2017) tried to look into the consequences of commodity expenditures (oil and copper prices), pastime charge and change price - some of the important macroeconomic elements the use of records for the years 20042016. Employing Autoregressive Distributive Lag Model (ARDL) and Vector Error Correction Model (VECM) for each the short run and long run separately, they found all the variables having sizeable effects on the performance of stock market both in the short run and long run jointly. In terms of disjoint effect, amongst all the explanatory variables, while copper expenditures and pastime quotes have a large influence, in the long run, copper expenditures and change fees can have an effect on the stock market overall performance in the quick run.

Otieno et al. (2017) examined how activity price affects inventory market returns in Kenya gathering month-to-month records from 1st January 1993 to 31st December 2015 and employing ARFIMA and Granger causality model. The end result indicated that macroeconomic variables - 3-month T-bill, lending fee are partially integrated with stock market returns. Moreover, three months T-bill and lending fee Granger purpose stock market returns undesirably in the long run which in flip signifies that each shares and T-bills are rival investments. Furthermore, ARFIMA primarily based Granger causality exhibits that inventory market returns lead the 3-month T-bill and lending price having a negative signal in the quick run sooner or later implies that promising macroeconomic surroundings can be resulted via ensuring prosperous inventory market.

For Nigeria, Bala and Hassan (2018) displayed Exchange Rate and Stock Market Interactions to test the existence of empirical linkage between the aforementioned two variables. Annual statistics of 1985-2015 had been gathered for ARDL and Granger causality testing. The result indicated that the trade price and economic increase are high-quality and widespread on the 
stock market whilst the money provide is negative. Furthermore, there exists a unidirectional causality (stock market money supply).

A good-sized find out about for Arabian countries (i.e. Egypt, Jordan, Kuwait, Oman, and Qatar) was performed with the aid of Al-Naif (2018). Using monthly data, the author applied VAR, Johansen cointegration strategy and Granger causality and located mixed consequences (i.e. VAR affirms the presence of sizeable bad affiliation (interest rate versus inventory market index) for Egypt while this relationship is positive for Jordan and Oman; however the insignificant relationship was once evident for Kuwait and Qatar). Cointegration analysis advised that long run cointegrating relationship holds for Qatar alone whilst Granger causality confirms bidirectional causal relationship for Jordan and unidirectional causal relationship (stock market index pastime rate) for Egypt only.

\subsection{Context of Bangladesh}

In the context of 4 South Asian international locations - Bangladesh, India, Pakistan, and Sri Lanka, Muhammad et al. (2002) employed cointegration, VECM and Granger causality strategy to investigate the association between exchange rate and stock rate empirically. Using month-to-month records from January 1994 to December 2000, they found no cointegrating relationship between these two variables both in the short run and long run whilst Granger causality test bidirectional causal relationship solely for Bangladesh and Sri Lanka. two Rahman and Uddin (2009) studied three nations from South Asia - Bangladesh, India, and Pakistan to look at the empirical the relationship between one of the macroeconomic indicators - exchange rate and stock prices. Covering month-to-month statistics from January 2003 to June 2008 and the usage of Johansen co-integration as well as Granger causality approach, he discovered no co-integrating relationship and no causality between the viewed variables.

With an intention to investigate adjustments in interest rates and exchange rate can exert influence on the overall performance of Bangladesh's inventory market, Banerjee and Adhikary (2009) employed Johansen multivariate cointegration technique, VECM, and VAR the use of month-to-month statistics ranging from January 1983 to December 2006. The learn about observed ambiguous effects when concern to various methods. They concluded the existence of cointegrating relationship amongst the regarded variables according to Johansen cointegration analysis. VECM confirmed that there exists long-run relationship among the studied variables and a unidirectional causal relationship running from interest rates and exchange rates to stock market performance. Moreover, they found counterintuitive results while considering lagged terms of both the explanatory variables; positive effect for interest rates and negative effect for exchange rates. On the contrary, VAR consequences cautioned no way causal relationship and insignificant relationship amongst the variables.

A find out about for each creating and developed countries (i.e. Australia, Bangladesh, Canada, Chile, Colombia, Germany, Italy, Jamaica, Japan, Malaysia, Mexico, Philippine, South Africa, Spain, and Venezuela) was once performed via Alam and Uddin (2009). They utilized panel data evaluation to monthly records (January 1988-March 2003) for all the countries. The study concluded that interest rates and changes in interest rates have mixed 
conclusions for individual countries. For Bangladesh, a significant negative relationship was found in both cases - interest rates vs share price and changes in interest rates vs changes in share prices.

Muktadir-Al-Mukit (2012) attempted to look at the consequences of interest rate and exchange price on the volatility of market index (general market index) at Dhaka inventory alternate the use of month-to-month information from 1997 to 2010. Employing cointegration analysis, VECM, variance decomposition, and Granger causality, the study observed the existence of a negative relationship with the exchange rate and positive relationship with interest rate. Moreover, Granger causality printed that there is a unidirectional causal relationship (stock market index exchange rate and from interest rate in stock market index).

Previous research reviewed in this part both from the context of Bangladesh and the countries other than Bangladesh grant massive proof of the presence of vagueness of findings, that is, the association of stock market overall performance and selected macroeconomic indications are now not concrete relations. Along with this issue, the introduction of DS30 and DSEX two new indices other than the already present index (DGEN) justifies the present day study.

\section{Research Methodology}

\subsection{Data}

This research aims to examine the long-term connection in Bangladesh between stock market performance and a few chosen macroeconomic indicators. Monthly information are used for empirical evaluation from January 2013 to October 2018 and information are gathered from the Bangladesh Bank and Dhaka Stock Exchange's Monthly Economic Trends. Two indices representing the stock market performance (DSE Broad Index-DSEX and DSE 30 Index-DS30) and selected macroeconomic variables (Exchange rate-EXG, Inflation-INF, Interest rate-INT and 91-days Treasury Bill Rate-TBill) are observed to address the objective of the study. Variables of this study are selected based on prior empirical studies (i.e. Muktadir-Al-Mukit, 2012, Mbulawa, 2015, Kuwornu, 2012). The broad index of the exchange covering $97 \%$ equity of the capital market in Bangladesh is known as DSEX while DS30 stands for the investable index of the exchange which covers $51 \%$ equity in the capital market of Bangladesh. The exchange rate is evaluated against 1 US dollar as the quantity of taka. The rate of inflation (as a proportion) is supported by the index of consumer price (CPI). The proportion of CPI, interest rate and bill rate of the Treasury is evaluated. The data were transformed logarithmically to maintain statistical simplicity and to obtain some desirable statistical properties for the estimates.

\subsection{Model Specification}

A current study specifies the following econometric models to test the relationship between stock market performance subject to different macroeconomic variables:

Model 1: $L D S E X_{t}=\beta_{0+} \beta_{1} L E X G_{t}+\beta_{2} L I N F_{t}+\beta_{3} L I N T_{t}+\beta_{4} L_{T B i l l}+\mu_{t} \ldots \ldots$ (1)

Model 2: $L D S 30_{t}=\alpha_{0+} \alpha_{1} L E X G_{t}+\alpha_{2} L_{I N F_{t}}+\alpha_{3} L_{I N T_{t}}+\alpha \operatorname{LTBill}_{t}+\epsilon_{t} \ldots \ldots . .(2)$

Where, 
LDSEX = Natural Logarithm of DSE broad index

LDS30 = Natural Logarithm of DSE 30 index

LEXG $=$ Natural Logarithm of the exchange rate

LINF $=$ Natural Logarithm of the inflation rate

LINT $=$ Natural Logarithm of interest rate

LTBill $=$ Natural Logarithm of Treasury bill rate

\subsection{Tests for Unit Root}

Before proceeding with standard time series modeling, it is highly required to check if any variables appear to have unit root problem alternatively termed as a non-stationarity problem. Because the unit root problem may cause spurious regression. In essence, the Augmented Dickey-Fuller (ADF) test and Phillips-Perron (PP) test are used to check the stationarity of the variables. The ADF test (1979) is performed to validate the null hypothesis $\mathrm{H}_{0}: \eta=0$ (non-stationary variables) against the alternative $\mathrm{H}_{1}: \eta<0$ (stationary variables) in the following regression:

$$
\Delta y_{t}=\mu+\eta y_{t-1}+\sum_{i=1}^{k} \Delta y_{t-i}+\varepsilon_{t}
$$

Where $\Delta$ denotes the first difference operator, $\varepsilon_{t}$ is a white noise error term and $\mathrm{k}$ is the number of lags in the dependent variable. If the null hypothesis is not rejected, then unthe it root is present, and rejection implies the stationarity of the series. Phillips and Perron (1988) test is also performed to justify the results of ADF. The Phillips-Perron test is performed to validate the null hypothesis of $\pi=0$ in the following regression:

$$
\Delta y_{t}=\pi y_{t-1}+\beta_{i} D_{t-i}+\varepsilon_{t}
$$

If the null hypothesis is rejected at $1 \%, 5 \%$ and $10 \%$ level of significance, it can be concluded that variable has no unit root i.e. variable is stationary. But if we fail to reject the null hypothesis then there exists a unit root problem and it can be solved by taking the first difference.

\subsection{Cointegration}

After having the order of integration, Johansen and Juselius (1990) co-integration approach can be performed to find out the long run association among variables. Johansen procedure basically targets to find out the rank of the matrix indicating the number of cointegrating vectors. Trace and Eigen-value test statistic are used for estimating the number of co-integrating vectors or equations. Trace statistic and Eigen-value statistic can be represented as follows: 


$$
\begin{aligned}
& \lambda_{\text {Trace }}(r)=-T \sum_{i=r+1}^{g} \operatorname{in}\left(1-\hat{\lambda}_{i}\right) \\
& \lambda_{\text {Max }}(r, r+1)=-T \ln \left(1-\hat{\lambda}_{r+1}\right)
\end{aligned}
$$

It is noted that $\lambda_{\text {Trace }}(r)$ is a joint test which examines the null hypothesis that cointegrating vectors are at most $r$ while alternative hypothesis examines the chance of having more than 1 cointegrating vectors (Brooks, 2008). On the other hand, $\lambda_{\operatorname{Max}}(r, r+1)$ carries out separate test on each Eigen value with the null hypothesis of $r$ cointegrating vector against an alternative $\mathrm{r}+1$ vector.

\section{Empirical Results and Discussion}

\subsection{Ordinary Least Square (OLS) Regression Model}

From the obtained results taken from Table 1, it is obvious that exchange rate, inflation rate, and Treasury bill rate has a positive impact on DSE broad index (DSEX) but interest rate has a negative impact on DSEX. Among these relationships, coefficients of the exchange rate and interest rate are statistically significant at 5\% level of significance. Here, the coefficients imply that $1 \%$ increase in the exchange rate can cause $1.93 \%$ increase in DSE broad index but $1 \%$ increase in market interest rate can cause a $0.6 \%$ decline in DSE broad index. Other two variables specifically inflation and Treasury bill are statistically insignificant. As we go through the Breusch-Godfrey serial correlation LM Test, it is found that there exists an autocorrelation problem among the variables, and regression becomes spurious.

Table 1. Model 1 - Dependent variable (LDSEX)

\begin{tabular}{|l|l|l|l|l|}
\hline Variable & Coefficient & Std. Error & t-Statistic & Prob. \\
\hline LEXG & 1.930751 & 0.596623 & 3.236133 & 0.0019 \\
\hline LINF & 0.187849 & 0.172328 & 1.090065 & 0.2797 \\
\hline LINT & -0.602018 & 0.116224 & -5.179793 & 0.0000 \\
\hline LTBill & 0.052623 & 0.027802 & 1.892788 & 0.0628 \\
\hline C & 0.733235 & 2.612614 & 0.280652 & 0.7799 \\
\hline R-squared & 0.711934 & & 8.476985 \\
\hline Adjusted R-squared & 0.694207 & S.D. dependent var & 0.138573 \\
\hline S.E. of regression & 0.076629 & Akaike info criterion & -2.230938 \\
\hline Sum squared residual & 0.381678 & Schwarz criterion & -2.070331 \\
\hline Log likelihood & 83.08282 & Hannan-Quinn criterion & -2.167143 \\
\hline F-statistic & 40.16069 & Durbin-Watson stat & 0.496177 \\
\hline Prob(F-statistic) & 0.000000 & \multicolumn{4}{l}{} \\
\hline Breusch-Godfrey Serial Correlation LM Test \\
\hline F-statistic & 45.94664 & \multicolumn{5}{l|}{ Prob. F(2,63) } & 0.0000 \\
\hline Obs*R-squared & 41.52878 & \multicolumn{5}{l|}{ Prob. Chi-Square (2) } & 0.0000 \\
\hline
\end{tabular}

Source: Authors' calculation. 
Similarly, we also have found spurious regression for Model 2 as there exists an autocorrelation problem (Table 2). This is attributed to the non-stationarity nature of the variable.

Table 2. Model 2 - Dependent variable: LDS30

\begin{tabular}{|c|c|c|c|c|}
\hline Variable & Coefficient & Std. Error & t-Statistic & Prob. \\
\hline LEXG & 1.186396 & 0.559286 & 2.121267 & 0.0377 \\
\hline LINF & 0.098432 & 0.161544 & 0.609322 & 0.5444 \\
\hline LINT & -0.622297 & 0.108951 & -5.711712 & 0.0000 \\
\hline LTBill & 0.054971 & 0.026062 & 2.109256 & 0.0388 \\
\hline C & 3.191085 & 2.449117 & 1.302953 & 0.1972 \\
\hline R-squared & 0.729839 & Mean dependent var & 7.483026 \\
\hline Adjusted R-squared & 0.713214 & S.D. dependent var & 0.134137 \\
\hline S.E. of regression & 0.071833 & Akaike info criterion & -2.360185 \\
\hline Sum squared residual & 0.335403 & Schwarz criterion & -2.199578 \\
\hline Log likelihood & 87.60647 & Hannan-Quinn criterion & -2.296390 \\
\hline F-statistic & 43.89943 & \multicolumn{5}{|l|}{ Durbin-Watson stat } & 0.586078 \\
\hline Prob(F-statistic) & 0.000000 & \multicolumn{5}{|l|}{ Prob. Chi-Square (2) } & 0.0000 \\
\hline \multicolumn{5}{|l|}{ Breusch-Godfrey Serial Correlation LM Test } \\
\hline F-statistic & 35.50459 & \multicolumn{5}{|l|}{ Prob. F(2,63) } & 0.0000 \\
\hline Obs*R-squared & 37.09181 & Prob \\
\hline
\end{tabular}

Source: Authors' calculation.

\subsection{Test for Stationarity - Unit Root Test}

Results obtained from both ADF and PP tests (Table 3) suggest that all the variables contain unit root in the level form that is variables are non-stationary at level but become stationary in the first-differenced form at $1 \%$ level of significance. Therefore, it can be concluded that LDSEX, LDS30, LEXG, LINF, LINT, and LTBill are integrated of order one, I (1).

Table 3. Test results of Unit Root

\begin{tabular}{|c|c|c|c|c|c|c|}
\hline \multirow[t]{2}{*}{ Variables } & \multicolumn{3}{|l|}{ ADF } & \multicolumn{3}{|l|}{$\mathbf{P P}$} \\
\hline & level & $\begin{array}{l}\text { First } \\
\text { difference }\end{array}$ & Remarks & Level & $\begin{array}{l}\text { First } \\
\text { difference }\end{array}$ & Remarks \\
\hline LDSEX & $\begin{array}{l}-1.575853 \\
(0.4894)\end{array}$ & $\begin{array}{l}-8.260018 * * * \\
(0.0000)\end{array}$ & $\mathrm{I}(1)$ & $\begin{array}{l}-1.470239 \\
(0.5427)\end{array}$ & $\begin{array}{l}-8.404166^{* * * *} \\
(0.0000)\end{array}$ & $\mathrm{I}(1)$ \\
\hline LDS30 & $\begin{array}{l}-1.829889 \\
(0.3633)\end{array}$ & $\begin{array}{l}-8.990088 * * * \\
(0.0000)\end{array}$ & $\mathrm{I}(1)$ & $\begin{array}{l}-1.641765 \\
(0.4561)\end{array}$ & $\begin{array}{l}-9.527725 * * * \\
(0.0000)\end{array}$ & $\mathrm{I}(1)$ \\
\hline LEXG & $\begin{array}{l}0.726604 \\
(0.9919\end{array}$ & $\begin{array}{l}-5.018228 * * * \\
(0.0001)\end{array}$ & $\mathrm{I}(1)$ & $\begin{array}{l}1.271473 \\
(0.9983)\end{array}$ & $\begin{array}{l}-4.886241 * * * \\
(0.0001)\end{array}$ & $\mathrm{I}(1)$ \\
\hline LINF & $\begin{array}{l}-0.944454 \\
(0.7682)\end{array}$ & $\begin{array}{l}-10.24704 * * * \\
(0.0001)\end{array}$ & $\mathrm{I}(1)$ & $\begin{array}{l}-0.994248 \\
(0.7510)\end{array}$ & $\begin{array}{l}-10.20566^{* * * *} \\
(0.0001)\end{array}$ & $\mathrm{I}(1)$ \\
\hline LINT & -1.411588 & $-3.895155^{*} * *$ & $\mathrm{I}(1)$ & -1.059199 & $-3.950107 * * *$ & $\mathrm{I}(1)$ \\
\hline
\end{tabular}




\begin{tabular}{|l|l|l|l|l|l|l|}
\hline & $(0.5714)$ & $(0.0034)$ & & $(0.7272)$ & $(0.0029)$ & \\
\hline LTBill & 0.417008 & $-14.29789 * * *$ & $\mathrm{I}(1)$ & -2.302622 & $-20.64838 * * *$ & $\mathrm{I}(1)$ \\
& $(0.9823)$ & $(0.0000)$ & & $(0.1741)$ & $(0.0001)$ & \\
\hline
\end{tabular}

Source and Note: Authors' calculation. ${ }^{* *}$ denotes $1 \%$ significance level, and p-values are in the parentheses.

Table 4. Test result of Johansen Cointegration (Model 1)

\begin{tabular}{|c|c|c|c|c|c|c|}
\hline $\begin{array}{c}\text { Hypothesized } \\
\text { No. of CE(s) }\end{array}$ & $\begin{array}{c}\text { Trace } \\
\text { Statistic }\end{array}$ & $\begin{array}{c}0.05 \\
\text { Critical } \\
\text { value }\end{array}$ & Prob. & $\begin{array}{c}\text { Max-Eigen } \\
\text { Statistic }\end{array}$ & $\begin{array}{c}0.05 \\
\text { Critical } \\
\text { value }\end{array}$ & Prob. \\
\hline None $*$ & 85.65254 & 69.81889 & 0.0016 & 39.67132 & 33.87687 & 0.0091 \\
\hline At most 1 & 45.98122 & 47.85613 & 0.0742 & 22.41161 & 27.58434 & 0.2000 \\
\hline At most 2 & 23.56960 & 29.79707 & 0.2192 & 17.95240 & 21.13162 & 0.1316 \\
\hline At most 3 & 5.617201 & 15.49471 & 0.7402 & 5.447798 & 14.26460 & 0.6846 \\
\hline At most 4 & 0.169403 & 3.841466 & 0.6806 & 0.169403 & 3.841466 & 0.6806 \\
\hline
\end{tabular}

Source and Note: Authors' calculation. * denotes the rejection of null hypothesis at 5\% significance level.

Table 5. Normalized cointegrating coefficients (Model 1)

\begin{tabular}{|c|c|c|c|c|}
\hline LDSEX & LEXG & LINF & LINT & LTBill \\
\hline \multirow{2}{*}{1.000000} & -12.58614 & 0.347488 & 0.634249 & -0.621462 \\
& $(1.96149)$ & $(0.33104)$ & $(0.22190)$ & $(0.09882)$ \\
\hline
\end{tabular}

Source and note: Authors' calculation. Standard errors are in the parentheses.

Cointegrating Equation for Model 1:

$$
\text { LDSEX }=12.59 \text { LEXG }-0.38 \text { LINF }-0.63 \text { LINT + 0.62 LTBill }
$$

Both Trace and Maximum Eigen value statistic presented in table- 4 for model- 1 and in table- 6 for model-2 imply that there exists one cointegrating equation which is significant at $1 \%$ and 5\% levels. Results obtained from Table 4 also suggest that there is a long run relationship between DSE broad index (DSEX) and macroeconomic indicators (EXG, INF, INT, and TBill). Similarly, long-run relationship between DSE investable index (DS30) and macroeconomic indicators (EXG, INF, INT, and TBill) is ensured by results from table-6. The normalized Cointegration coefficients for model-1 are presented in Table 5. Since coefficients are normalized on LDSEX, interpretation of the coefficients must be reversed and normalized Cointegration equation can be written as equation (1) which implies the following results:

Ceteris paribus,

- A $1 \%$ increase in the exchange rate can cause $12.59 \%$ increase in DSE broad index (DSEX)

- A $1 \%$ increase in the inflation rate can cause $0.38 \%$ decline in DSE broad index (DSEX) 
- A $1 \%$ increase in interest rate can cause $0.63 \%$ decline in DSE broad index (DSEX)

- A $1 \%$ increase in Treasury bill rate can cause $0.62 \%$ increase in DSE broad index (DSEX)

Table 6. Test result of Johansen Cointegration (Model 2)

\begin{tabular}{|l|l|l|l|l|l|l|}
\hline $\begin{array}{l}\text { Hypothesized } \\
\text { No. of CE(s) }\end{array}$ & $\begin{array}{l}\text { Trace } \\
\text { Statistic }\end{array}$ & $\begin{array}{l}0.05 \\
\text { Critical } \\
\text { value }\end{array}$ & Prob. & $\begin{array}{l}\text { Max-Eigen } \\
\text { Statistic }\end{array}$ & $\begin{array}{l}0.05 \\
\text { Critical } \\
\text { value }\end{array}$ & Prob. \\
\hline None $*$ & 83.35480 & 69.81889 & 0.0028 & 39.39942 & 33.87687 & 0.0099 \\
\hline At most 1 & 43.95538 & 47.85613 & 0.1109 & 20.27705 & 27.58434 & 0.3223 \\
\hline At most 2 & 23.67834 & 29.79707 & 0.2144 & 16.63908 & 21.13162 & 0.1897 \\
\hline At most 3 & 7.039254 & 15.49471 & 0.5731 & 6.999212 & 14.26460 & 0.4892 \\
\hline At most 4 & 0.040042 & 3.841466 & 0.8414 & 0.040042 & 3.841466 & 0.8414 \\
\hline
\end{tabular}

Source and note: Authors' calculation. * denotes the rejection of null hypothesis at 5\% significance level.

Table 7. Normalized cointegrating coefficients (Model 2)

\begin{tabular}{|c|c|c|c|c|}
\hline LDS30 & LEXG & LINF & LINT & LTBill \\
\hline \multirow{2}{*}{1.000000} & -11.18197 & 0.591198 & 0.632178 & -0.603092 \\
& $(1.78332)$ & $(0.30619)$ & $(0.20463)$ & $(0.08994)$ \\
\hline
\end{tabular}

Source and note: Authors' calculation. Standard errors are in the parentheses.

The cointegrating equation for Model 2

$$
\text { LDS30 }=11.18 \text { LEXG }-0.59 \text { LINF }-0.63 \text { LINT }+0.60 \text { LTBill }
$$

Similarly, we can write the normalized Cointegration coefficient for Model 2 as equation (2) which implies:

Ceteris paribus,

- A $1 \%$ increase in the exchange rate can cause $11.18 \%$ increase in DSE 30 index (DS30)

- A $1 \%$ increase in inflation rate can cause $0.59 \%$ decline in DSE 30 index (DS30)

- A $1 \%$ increase in interest rate can cause $0.63 \%$ decline in DSE 30 index (DS30)

- A $1 \%$ increase in Treasury bill rate can cause $0.60 \%$ increase in DSE 30 index (DS30)

So, this paper summarizes the results of Johansen Cointegration analysis by concluding that both DSEX and DS30 index have stable long-run relationship with the selected macroeconomic indicators namely interest rate, exchange rate, inflation, and treasury bill.

\subsection{Granger Causality Test}

Cointegration between variables identifies the presence of at least one-way causality between them (Granger, 1988). As Cointegration is found, the Granger causality test can be applied to explore the direction of causality. The results are summarized for both models in Table 8 and 
Table 9.

Table 8. Test Result of Granger Causality (Model 1)

\begin{tabular}{|c|c|c|c|}
\hline Null Hypothesis & F-Statistic & Prob. & Causality \\
\hline LEXG does not Granger Cause LDSEX & 0.01407 & 0.9059 & No \\
\hline LDSEX does not Granger Cause LEXG & 31.6269 & 0.0000 & Yes \\
\hline \multicolumn{4}{|l|}{} \\
\hline LINF does not Granger Cause LDSEX & 1.14056 & 0.2894 & No \\
\hline LDSEX does not Granger Cause LINF & 0.56442 & 0.4552 & No \\
\hline \multicolumn{4}{|l|}{} \\
\hline LINT does not Granger Cause LDSEX & 5.40915 & 0.0231 & Yes \\
\hline LDSEX does not Granger Cause LINT & 8.41567 & 0.0050 & Yes \\
\hline \multicolumn{4}{|l|}{} \\
\hline LTBill does not Granger Cause LDSEX & 1.79741 & 0.1846 & No \\
\hline LDSEX does not Granger Cause LTBill & 5.11470 & 0.0270 & Yes \\
\hline
\end{tabular}

Source: Authors' calculation.

Results obtained from Table 8 imply that;

- DSE broad index (LDSEX) granger causes exchange rate (LEXG), interest rate (LINT) and Treasury bill rate (LTBill), which indicates that the lagged values of DSE broad index (LDSEX) can be used to forecast the values of exchange rate, interest rate, and Treasury bill rate.

- Only interest rate Granger causes the DSE broad index which means the lagged values of interest rate can be used to forecast the values of DSE broad index.

Similarly, results obtained from Table 9 suggest that DSE 30 index (DS30) granger causes exchange rate (LEXG), interest rate (LINT) and Treasury bill rate (LTBill) but only interest rate Granger causes the DSE 30 index.

Table 9. Test Result of Granger Causality (Model 2)

\begin{tabular}{|l|l|l|l|}
\hline Null Hypothesis & F-Statistic & Prob. & Causality \\
\hline LEXG does not Granger Cause LDS30 & 0.02812 & 0.8673 & No \\
\hline LDS30 does not Granger Cause LEXG & 29.0338 & 0.0000 & Yes \\
\hline \multicolumn{4}{|l|}{} \\
\hline LINF does not Granger Cause LDS30 & 1.06458 & 0.3059 & No \\
\hline LDS30 does not Granger Cause LINF & 2.07539 & 0.1544 & No \\
\hline \multicolumn{4}{|l|}{} \\
\hline LINT does not Granger Cause LDS30 & 6.61900 & 0.0123 & Yes \\
\hline LDS30 does not Granger Cause LINT & 6.35400 & 0.0141 & Yes \\
\hline \multicolumn{4}{|l|}{} \\
\hline LTBill does not Granger Cause LDS30 & 1.38060 & 0.2442 & No \\
\hline LDS30 does not Granger Cause LTBill & 5.15472 & 0.0265 & Yes \\
\hline
\end{tabular}

Source: Authors' calculation. 


\subsection{Impulse Response Function (IRF)}

An impulse response function shows the effect of shock (one standard deviation) on the dependent variable and carries out to the whole dependent variable through the lag structure. Figure 1 and Figure 2 show the impulse response function for DSE broad index (LDSEX) and DSE 30 index (LDS30) respectively. The horizontal axis measures the length of impulse response and the vertical axis measures the percentage of variation (innovation) over time. Impulse response function for LDSEX (Figure 1) shows that;

- Exchange rate shock has a positive impact on DSE broad index (DSEX) up to a $3^{\text {rd }}$ period and it becomes negative after the $3^{\text {rd }}$ period. But the positive impact has an upward trend up to the $2^{\text {nd }}$ period and then the trend goes downward.

- The shock of inflation rate has a positive impact on DSE broad index from the $2^{\text {nd }}$ period as it does not carry any impact in the $1^{\text {st }}$ period.

- Both the interest rate shock and Treasury bill rate shock have a negative impact on DSE broad index.

Response of LDSEX to LEXG

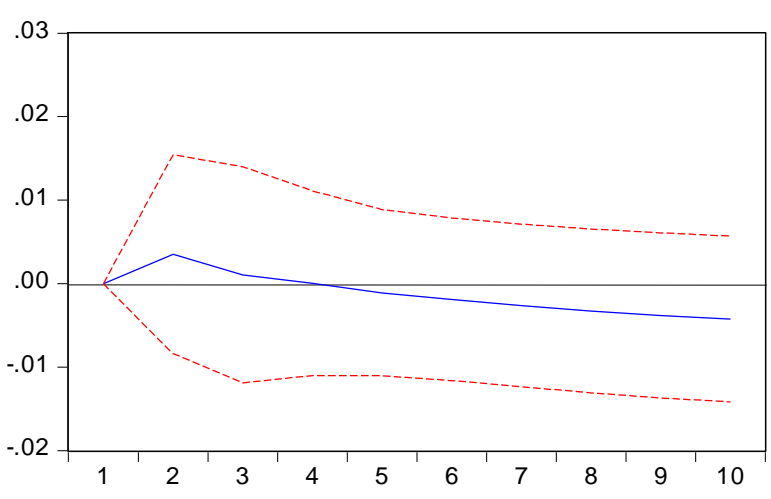

Response of LDSEX to LINT

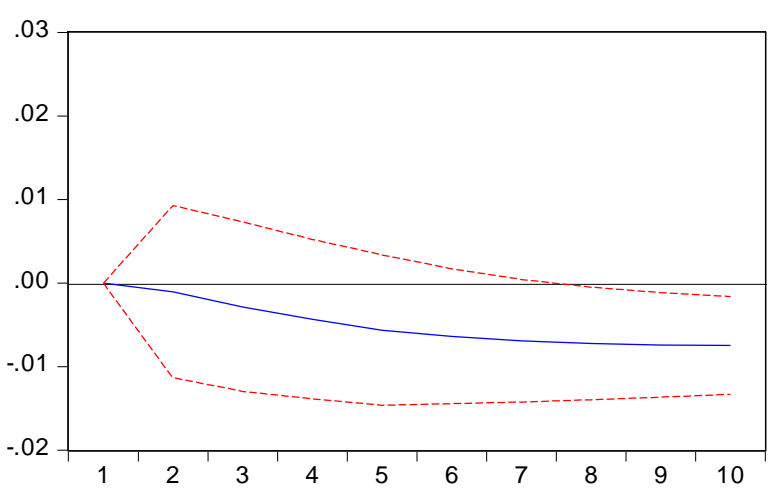

Response of LDSEX to LINF

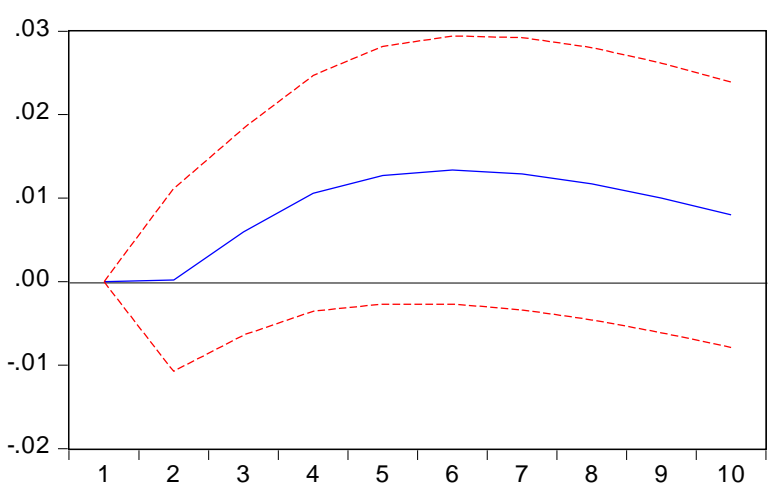

Response of LDSEX to LTBILL

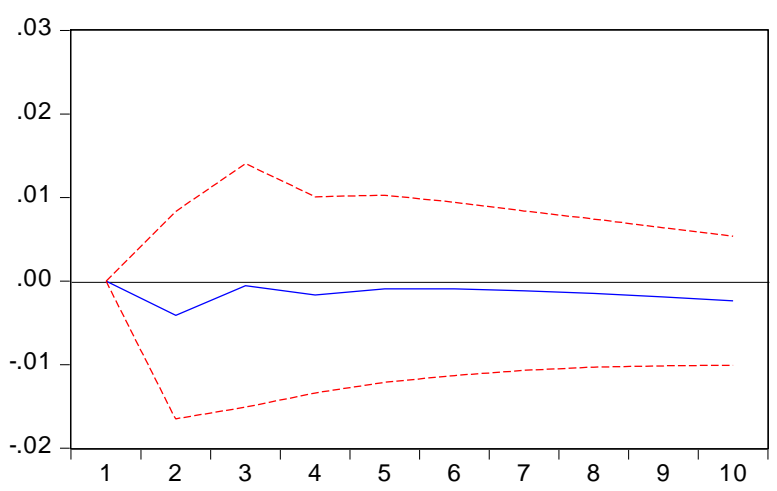

Figure 1. Impulse Response Function for LDSEX (Response to Cholesky One S.D. Innovations)

Source: Authors' presentation.

Impulse response function for LDS30 (Figure 2) shows that; 
- Exchange rate shock has a positive impact on DSE 30 index up to a $4^{\text {th }}$ period and it turns negative after $4^{\text {th }}$ period. But the positive impact has an upward trend up to the $2^{\text {nd }}$ period and then the trend becomes downward.

- The shock of inflation rate has a positive impact on the DSE 30 index from the $1^{\text {st }}$ period. The impact has an upward trend from the $1^{\text {st }}$ period to $5^{\text {th }}$ period and a downward trend from $6^{\text {th }}$ period to $10^{\text {th }}$ period. Stability of the shock has been observed in the $5^{\text {th }}$ and $6^{\text {th }}$ period.

- Interest rate shock has a negative impact on DSE 30 index.

- The Treasury bill shock has a negative impact on the DSE 30 index in the first two periods. After that, it becomes positive and fades away in the fourth period up to a $7^{\text {th }}$ period. Finally, the negative impact has been observed from $7^{\text {th }}$ period to $10^{\text {th }}$ period.

Response of LDS30 to LEXG

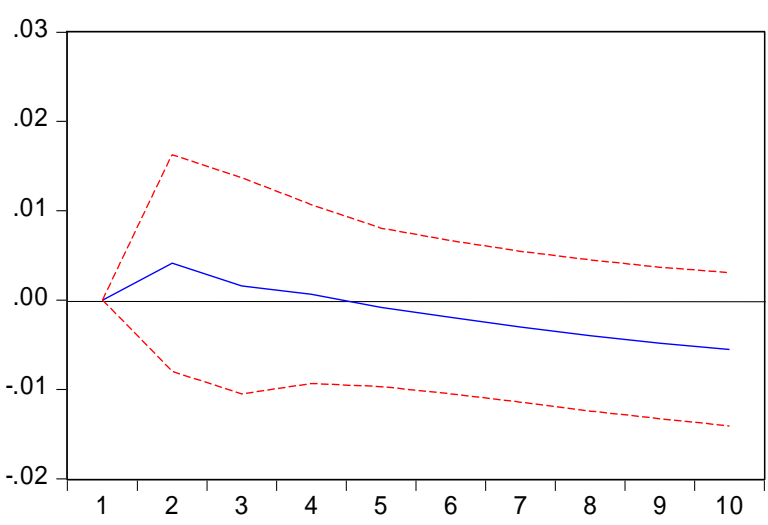

Response of LDS30 to LINT

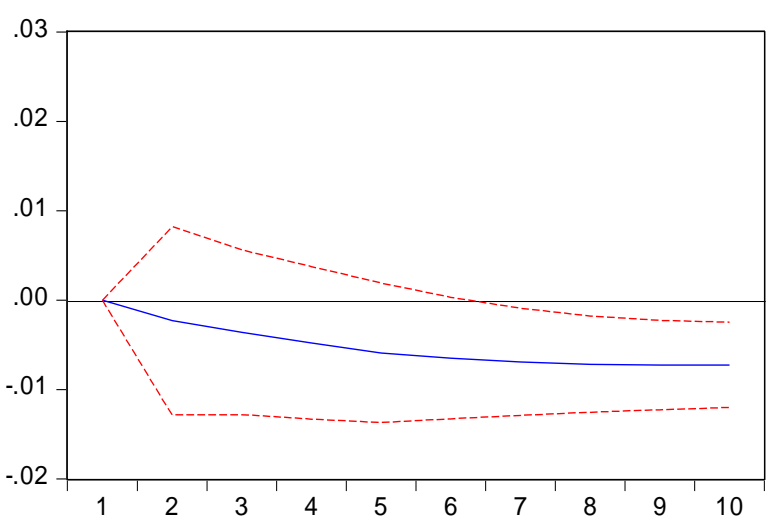

Response of LDS30 to LINF

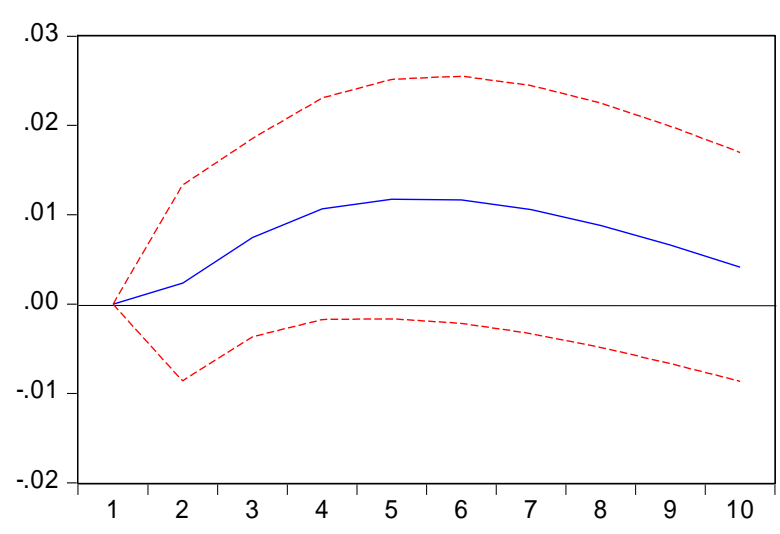

Response of LDS30 to LTBILL

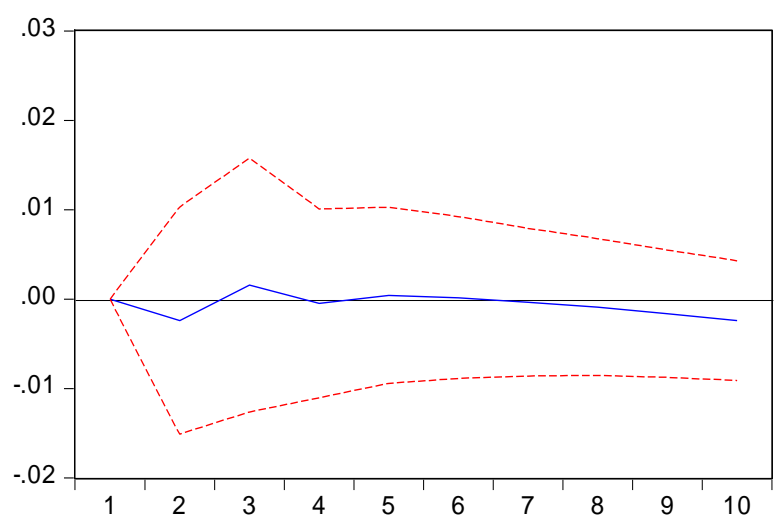

Figure 2. Impulse Response Function for LDS30 (Response to Cholesky One S.D. Innovations)

Source: Authors' presentation.

\section{Conclusion and Policy Imperatives}

The present research tries to explore the link between macroeconomic variables and stock market performance with a particular focus on two Dhaka Stock Exchange indices-DSEX 
and DS30. Empirical results are achieved by implementing suitable econometric techniques in line with the study's goal. Both Augmented Dickey-Fuller (ADF) and Phillips-Perron (PP) tests verify that all variables at their stage are non-stationary, which in turn provides a rationale for testing Johansen's cointegration strategy to check the long-term connection between the factors studied. The cointegration test by Johansen justifies the presence of a long-term connection between the factors described and described, while the causality of Granger affirms that unidirectional causality derives from DSE broad index (DSEX) to interest rate, inflation rate and exchange rate and bidirectional causality is evident for interest rate and DSE broad index (DSEX). The DSE 30 index (DS30) obtains very comparable outcomes. It can be summed up in a nutshell that exchange rate and treasury bill are strongly connected with improved results on the stock market. On the contrary, the rate of interest and inflation tend in the reverse direction to influence stock market performance. The research results favor Muktadir-Al-Mukit (2012) and Kuwornu (2012) results and contradict Rahman \& Uddin (2009) results. A sound and healthy inventory market is crucial to any economy's stable financial development. Healthy stock markets require positive measures with regard to significant macroeconomic indices i.e. inflation rate, treasury bill rate, interest rate, exchange rates, etc. Given that the present research shows a important connection between macroeconomic variables and stock market results, policymakers can include the results while formulating measures aimed at stabilizing the stock market and keeping healthy economic growth. Furthermore, the establishment of a strong regulatory framework concerning the stock market is increasingly important to oversee any kind of irregularities (i.e. fraudulence) of the stock market.

\section{References}

Aggarwal, R. (2003). Exchange rates and stock prices: A study of the US capital markets under floating exchange rates.

Ahmad, M. I., Rehman, R. U., \& Raoof, A. (2010). Do interest rate, exchange rate effect stock returns? A Pakistani perspective. International Research Journal of Finance and Economics, 50, 146-150.

Alam, M. D., \& Uddin, G. (2009). Relationship between interest rate and stock price: empirical evidence from developed and developing countries. International Journal of Business and Management (ISSN 1833-3850), 4(3), 43-51.

https://doi.org/10.5539/ijbm.v4n3p43

AL-Naif, K. L. (2017). The Relationship Between Interest Rate and Stock Market Index: Empirical Evidence from Arabian Countries.

Ayopo, B. A., Isola, L. A., \& Olukayode, S. R. (2016). Stock market response to economic growth and interest rate volatility: Evidence from Nigeria. International Journal of Economics and Financial Issues, 6(1), 354-360.

Bala S. A. R., \& Hassan, A. (2018). Exchange rate and stock market interactions: Evidence from Nigeria. Arabian Journal of Business and Management Review, 8(1). 


\section{Macrothink}

Business and Economic Research ISSN 2162-4860 2019, Vol. 9, No. 3

Banerjee, P. K., \& Adhikary, B. K. (2009). Dynamic effects of changes in interest rates and exchange rates on the stock market return in Bangladesh. Ritsumeikan Journal of Asia Pacific Studies, 25, 119-133.

Bekhet, H. A., \& Matar, A. (2013). Co-integration and causality analysis between stock market prices and their determinates in Jordan. Economic Modelling, 35, 508-514. https://doi.org/10.1016/j.econmod.2013.07.012

Bhattacharya, B., \& Mukherjee, J., (2003). Causal Relationship between Stock Market and Exchange Rate, Foreign Exchange Reserves and Value of Trade Balance: A Case Study for India. This paper was presented at the Fifth Annual Conference on Money and Finance in the Indian Economy.

Blanchard, O. J. (1981). Output, the stock market and interest rate. American Economic Review, 71(1), 132-143.

Brooks, C. (2008). Introductory Econometrics for Finance. (2nd ed.). Cambridge. Cambridge University Press. https://doi.org/10.1017/CBO9780511841644

Chen, N. F., Roll, R., \& Ross, S. A. (1986). Economic forces and the stock market. Journal of Business, 383-403. https://doi.org/10.1086/296344

Choudhry, T. (2001). Inflation and rates of return on stocks: evidence from high inflation countries. Journal of International Financial Markets, Institutions and Money, 11(1), 75-96. https://doi.org/10.1016/S1042-4431(00)00037-8

Dickey, D. A., \& Fuller, W. A. (1979). Distribution of the estimators for autoregressive time series with a unit root. Journal of the American statistical association, 74(366a), 427-431. https://doi.org/10.1080/01621459.1979.10482531

Dornbusch, R., \& Fischer, S. (1980). Exchange rates and the current account. The American Economic Review, 70(5), 960-971.

Eita, J. H. (2014). Interest rate and stock market returns in Namibia. The International Business \& Economics Research Journal (Online), 13(4), 689.

https://doi.org/10.19030/iber.v13i4.8677

Giovannini, A., \& Jorion, P. (1987). Interest rates and risk premia in the stock market and in the foreign exchange market. Journal of International Money and Finance, 6(1), 107-123. https://doi.org/10.1016/0261-5606(87)90016-7

Granger, C. W. J. (1988). Some recent developments in the concept of causality. Journal of Econometrics, 39, 199-211. https://doi.org/10.1016/0304-4076(88)90045-0

Gupta, R., \& Modise, M. P. (2013). Macroeconomic variables and South African stock return predictability. Economic Modelling, 30, 612-622.

https://doi.org/10.1016/j.econmod.2012.10.015

Hicks, J. R. (1937). Mr. Keynes and the" classics"; a suggested interpretation. Econometrica: journal of the Econometric Society, 147-159. https://doi.org/10.2307/1907242 


\section{Macrothink}

Business and Economic Research ISSN 2162-4860 2019, Vol. 9, No. 3

Hsing, Y. (2011). The stock market and macroeconomic variables in a BRICS country and policy implications. International Journal of Economics and Financial Issues, 1(1), 12-18.

Johansen, S., \& Juselius, K. (1990). Maximum Likelihood Estimation and Inference on Cointegration with Applications to Demand for Money. Oxford Bulletin of Economics and Statistics, 52, 169-210. https://doi.org/10.1111/j.1468-0084.1990.mp52002003.x

Joseph, N. A., \& Vezos, P. (2006). The Sensitivity of US Bank's Stock Returns to Interest Rate and Exchange Rate Changes. Managerial Finance, 32(2), 182-199.

https://doi.org/10.1108/0307435061064193

Khan, Z., Khan, S., Rukh, L., Imdadullah, K., \& Rehman, W. (2012). Impact of interest rate, exchange rate and inflation on stock returns of KSE 100 index. International Journal of Economic Research.

Kuwornu, J. K. (2012). Effect of macroeconomic variables on the Ghanaian stock market returns: A co-integration analysis. Agris on-line Papers in Economics and Informatics, 4(2), 15.

Li, Y., \& Huang, L. (2008, April). On the Relationship between stock return and exchange rate: evidence on China. In Chinese Economic Association (UK/Europe) Conference Papers.

Lim, S. Y., \& Sek, S. K. (2014), Exploring the inter-relationship between the volatilities of exchange rate and stock return. Procedia Economics and Finance, 14, 367-376.

Maysami, R., Howe, L., \& Hamzah, M. (2004), Relationship between macroeconomic variables and stock market indices: co-integration evidence from stock exchange of Singapore's All-S Sector Indices. Jurnal Pengurusan, 24, 47-77.

https://doi.org/10.17576/pengurusan-2005-24-03

Mbulawa, S. (2015). Stock market performance, interest rate and exchange rate interactions in Zimbabwe: A cointegration approach. International Journal of Economics, Finance and Management, 4(2).

Mgammal, M. H. H. (2012). The effect of inflation, interest rates and exchange rates on stock prices comparative study among two GCC countries. International Journal of Finance and Accounting, 1(6), 179-189.

Modigliani, F., \& Cohn, R. A. (1979). Inflation, Rational Valuation, and the Market. Financial Analysis Journal, 35(2), 24-44. https://doi.org/10.2469/faj.v35.n2.24

Mohammed, A. M. T., Wisam R., Hassama, A., \& Bin Amin, F. M. (2007). Effects of Macroeconomic Variables on Stock Prices in Malaysia: An Approach of Error Correction Model. International Islamic University Malaysia. Jalan Gombak-53100, Kuala Lumpur, Malaysia.

Mouna, A., \& Anis, J. (2016). Market, interest rate, and exchange rate risk effects on financial stock returns during the financial crisis: AGARCH-M approach. Cogent Economics \& Finance, 4(1), 1125332. https://doi.org/10.1080/23322039.2015.1125332 
Msindo, Z. H. (2016). The impact of interest rates on stock returns: empirical evidence from the JSE Securities Exchange (Doctoral dissertation).

Muhammad, N., Rasheed, A., \& Husain, F. (2002). Stock Prices and Exchange Rates: Are they Related? Evidence from South Asian Countries [with Comments]. The Pakistan Development Review, 535-550. https://doi.org/10.30541/v41i4IIpp.535-550

Musawa, N., \& Mwaanga, C. (2017). The Impact of Commodity Prices, Interest Rate and Exchange Rate on Stock Market Performance: Evidence from Zambia. Journal of Financial Risk Management, 6(03), 300. https://doi.org/10.4236/jfrm.2017.63022

Muktadir-al-Mukit, D. (2012). Effects of Interest Rate and Exchange Rate on Volatility of Market Index at Dhaka Stock Exchange. Journal of Business and Technology (Dhaka), 7(2), 1-18. https://doi.org/10.3329/jbt.v7i2.16451

Muktadir-Al-Mukit, D. (2013). The effects of interest rates volatility on stock returns: Evidence from Bangladesh. International Journal of Management and Business Research, 3(3), 269-279.

Nieh, C. C., \& Lee, C. F. (2001). Dynamic Relationship between Stock Prices and Exchange Rates for G-7 Countries. Quarterly Review of Economics and Finance, 41, 477-490. https://doi.org/10.1016/S1062-9769(01)00085-0

Otieno, D. A., Ngugi, R. W., \& Wawire, N. H. (2017). Effects of Interest Rate on Stock Market Returns in Kenya. International Journal of Economics and Finance, 9(8), 40. https://doi.org/10.5539/ijef.v9n8p40

Paramati, S. R., \& Gupta, R. (2013). An empirical relationship between exchange rates, interest rates and stock returns. Interest Rates and Stock Returns.

https://doi.org/10.2139/ssrn.2336043

Phillips, P. C. B., \& Perron, P. (1988), Testing for a unit root in time series regression. Biometrika, 75, 335-346. https://doi.org/10.1093/biomet/75.2.335

Rahman, M. L., \& Uddin, J. (2009). Dynamic relationship between stock prices and exchange rates: Evidence from three South Asian countries. International Business Research, 2(2), 167. https://doi.org/10.5539/ibr.v2n2p167

Rahman, M. T., Hossain, S.Z., \& Habibullah, M. (2017). Stock Market Crash in Bangladesh: The Moneymaking Psychology of Domestic Investors. American Journal of Theoretical and Applied Business, 3(3), 45-53. https://doi.org/10.11648/j.ajtab.20170303.12

Roll, R. (1992). Industrial structure and comparative behavior of international stock indices. $J$. Financ. 47, 3-41. https://doi.org/10.1111/j.1540-6261.1992.tb03977.x

Saha, S. (2012). Stock market crash of Bangladesh in 2010-11: Reasons \& roles of regulators. ARCADA, 1-63.

Sensoy, A., \& Sobaci, C. (2014). Effects of volatility shocks on the dynamic linkages between exchange rate, interest rate and the stock market: The case of Turkey. Economic 
Modelling, 43, 448-457. https://doi.org/10.1016/j.econmod.2014.09.005

Soenen, L. A., \& Hennigar, E. S. (1988). An analysis of exchange rates and stock prices: The US experience between 1980 and 1986. Akron Business and Economic Review, Winter, 7-16.

\section{Copyright Disclaimer}

Copyright for this article is retained by the author(s), with first publication rights granted to the journal.

This is an open-access article distributed under the terms and conditions of the Creative Commons Attribution license (http://creativecommons.org/licenses/by/3.0/). 